\title{
Time and spatial trends in landing per unit of effort as support to fisheries management in a multi-gear coastal fishery
}

\author{
P. Leitão ${ }^{a}$, L. Sousa ${ }^{a}$, M.Castrob ${ }^{b}$ A. Campos ${ }^{a, b}$
}

a IPMA, Instituto Português do Mar e da Atmosfera, Rua Alfredo Magalhães Ramalho 6, 1495165 Algés, Portugal.

b CCMAR, Centro de Ciências do Mar, Universidade do Algarve, 8005-139 Faro, Portugal.

*Corresponding author: Pedro Leitão. E-mail: pedro.leitao@ipma.pt (1)

\section{Abstract}

Landings by the multi-gear coastal fleet operating off the Portuguese continental coast include near 300 species, from which only a few are the object of management plans. In this study, daily landings ( $k g$ trip $-^{1}$ ) are used, along with an effort indicator, vessel length overall (LoA), to obtain landings per unit of effort (LPUE) as a proxy for the species relative abundance for a total of 48 species. LPUE indices were then used as a response variable in linear models where year (2012-2016), season, region (north and south) and NAO index were included as explanatory variables. Season and region effects were found to significantly affect species abundance for a total of 41 and 40 species respectively, while interannual effects were found to be significant for 19 species, and finally, the NAO index for 3 species. Global LPUE density maps are presented for a number of selected species and a subsample of trips where VMS records were available. For the species analysed, it is proposed that geographic and seasonal changes in LPUE indexes can be used to understand trends in abundance and obtain information that can be used in support of the definition of regional management plans. 


\section{INTRODUCTION}

In the European Union (EU), the principles underlying the Common Fisheries Policy (CFP) focus on long-term sustainability of marine resources. Fisheries were recognized to be dependent on healthy marine ecosystems, requiring the integration of the fisheries sector in other policies dealing with marine activities, namely the Integrated Maritime Policy (IMP) and its environmental pillar, the Marine Strategy Framework Directive (MSFD). An important aspect of these policies is the implementation of the ecosystem-based approach to fisheries management (EAFM), which became a central issue under the CFP, requiring information on the state of the marine environment, including indicators of fishing pressure, both for target and non-target species. Emphasis was placed on the need for a regionalized approach to fisheries management, with the establishment of fishery-based management plans and mitigation measures to be tailored to specific fisheries. Single species management will be replaced by multi-species long-term plans, while the spatial component plays an increasingly important role as a broader set of ecosystem interactions need to be considered.

For a sustainable fishing, management measures have evolved from control of catches (e.g., total allowable captures (TACs) and quotas) to fishing effort limitations and technical conservation measures, including gear restrictions, species minimum conservation reference sizes (MCRS) and real time closures (1). A combination of these types of measures is used in European fishery policies. The EAFM calls upon a fleet- and area-based approach to fisheries management (Council Regulation (EC) No 1343/2007) increasingly requiring the integration of fisheries-dependent data.

The evolution of methodologies for the assessment and management of fishing resources took place in parallel with important changes in the collection of data. Currently, most of the

51 information relevant to fisheries management in the EU has been obtained either through vessel research surveys or fleet monitoring programs at the scope of the Data Collection

53 Framework (DCF). In the last two decades, new mandatory procedures evolved, to improve and standardize fisheries data throughout the EU (2). Large and more reliable datasets are 
generated, and statistical modelling can then be applied to retrieve crucial fisheries information

such as the identification of exploited species and their distribution (3-5). The International

Council for the Exploration of the Sea (ICES), the entity responsible for providing advice on fisheries issues to the EU, has identified as a major objective, in its Science Plan, the development of effective mechanisms to use monitoring and surveillance data to support scientific advice (6).

The use of fisheries-dependent data is particularly useful in fisheries advice in fisheries where a high number of commercial species are exploited, from which only some are subject to formal assessment by ICES, resulting in TACs and quotas. For these areas, alternative management methods should be developed including area-specific management based on easily accessible fisheries dependent data. This approach assumes particular importance for fleets not covered by onboard sampling programs $(7,8)$.

Traditional stock assessment has relied on fisheries independent surveys to evaluate the biomass of exploited resources $(9,10)$. In the absence of this information, fisheries dependent data, such as catch per unit of effort (CPUE), represents the best available indicator of abundance (11-13). CPUE data are mainly gathered through national sampling programs where onboard observers register, for specific trips, the catch composition (number, weight and sizes of target and bycatch species) and respective fishing effort (hours of fishing, type, number, and size of gears).

For data deficient fleets, landings, instead of catches, can be used to obtain an alternative abundance index, landings per unit of effort (LPUE) $(14,15)$. Landings, combined with georeferenced data on the fishing activity, can provide information on stock trends at a regional level, allowing closures in space and time (16). Near real-time closures (RTCs) based on daily high-definition fishing maps of CPUE are beneficial to fisheries, in particular for heavily fished demersal species $(17,18)$. Iceland and Scotland rely on georeferenced catch data to define RTCs, limiting fishing in particular areas and ensuring sustainability (17). 
81 The multi-gear fishing fleet operating on the Portuguese continental coast (ICES Division IXa)

82 accounts for $96 \%$ of the total number of vessels, employing $69 \%$ of fishers and being

83 responsible for $31 \%$ of the landings in weight and $59 \%$ in value (19). This complex fleet

84 operates year-round, over a great variety of ecosystems, adapted to regional and seasonal

85 availability of resources. Most vessels are licensed for multiple fixed fishing gears, such as

86 gillnets and trammel nets, longlines, traps and pots, to capture a great diversity of benthic,

87 demersal and pelagic species (fish, shellfish, cephalopods, and crustaceans). Due to

88 limitations of crew size and well-being conditions, only a small fringe of the multi-gear fleet can

89 accommodate onboard observers and is monitored through the EU Data Collection

90 Framework (DCF) program (20).

91 The objective of this study is to illustrate the utility of using daily landing records and a measure

92 of effort to obtain LPUE indexes as a proxy of abundance for a high number of species

93 captured by a multi-gear, multi-species fleet, and relate LPUE with environmental information.

94 Short term trends (2012-2016) were obtained for a large number of species. For a selection

95 of species, the utility of using available georeferenced information given by VMS data was

96 demonstrated in mapping LPUE, illustrating spatial and time patterns in exploitation that can

97 contribute do define regional management plans. 
MATERIALS AND METHODS

100

\section{Data sources}

101 The Portuguese multi-gear fleet, operating mainly nets, traps and longlines, account for low bycatch when compared to purse seine and bottom trawlers, and generally take an opportunistic "all species are valuable" approach, discarding only species interdicted or those

104 with no commercial value (21-23). In such conditions, landings and catches are closely related and, in the absence of catch per unit of effort (CPUE), landings per unit of effort (LPUE) are considered as a good proxy for species abundance (24).

107 The data analysis refers to the multi-gear coastal fleet operating off the continental Portuguese coast, comprising a total of 492 vessels greater than 9 meters in length. Although most vessels use different types of static gear, a small fleet sub-segment uses dredges all year round to exclusively target bivalves. For each fishing trip, the data consisted of daily landings by species and technical characteristics of the vessels. For a sample of 165 vessels greater than 15 meters, VMS records associated with the fishing trips were also available.

Landings data

114 Daily landings included date, landing port, vessel ID, species identification (common name 115 and the 3-alpha FAO code) and landings in weight $(\mathrm{kg})$ and value $\left(€ \mathrm{~kg}^{-1}\right)$. for the 492 vessels belonging to the multi-gear coastal fleet. The original landings dataset comprised a total of

117257,134 fishing trips and 297 species. Three criteria were applied in sequence, to eliminate very rare species and/or trips with very low catches: (1) selection of the 100 species with higher landing frequencies, (2) based on the previous 100 species, selection of the 50 species with higher total landings (in weight), (3) for each of these 50 species, selection of the trips that landed more than $10 \%$ of the average daily landing of that species. In addition, the genus Microchirus was removed due to duplicated records as genus and species. The application of these criteria resulted in a total of 48 species captured in 247,252 trips, representing a loss of $3.8 \%$ of the original number of trips. 
126 The technical characteristics of the vessels comprised length overall (LoA), gross tonnage $127(\mathrm{GT})$, vessel power in $\mathrm{kW}$, year of construction and port of register.

128 Regarding VMS, the coastal fleet of interest is composed of vessels with length overall (LoA) 129 greater than 9 meters, but VMS systems are only installed in some vessels larger than 12 130 meters and in all vessels larger than 15 meters. Vessels between 12 and 15 meters are 131 exempt from the obligation to have the monitoring equipment if they operate exclusively within 132 territorial waters or spend less than 24 hours at sea. Due to this, of the 492 vessels in the multi-gear coastal fleet only, 165 were equipped with VMS, representing approximately 90000 134 trips.

135 VMS positioning data for each vessel consists of a succession of geographical locations 136 (latitude, longitude), timestamp, speed, and course, received by a 'blue-box' (satellite-tracking 137 device installed on board the fishing vessels). This information is transmitted via satellite to 138 the Fisheries Control Centre every 2 hours.

139 At an initial data processing stage, VMS data were filtered to exclude records with duplicate 140 or erroneous values. The data analysis proceeded with the identification of fishing trips (FT) 141 for the 165 vessels. This identification was carried out by partitioning the VMS data into 142 sections starting with departure from a port and ending at the arrival to the same or a different 143 port. Each one of these sections, corresponding to a fishing trip, is associated to a landing 144 declaration. The objective was, for each species, to provide spatial-temporal information on 145 fishing grounds and relative abundance, together with information on fishing effort.

146 The VMS data, landings, and vessel technical characteristics were provided in an anonymized 147 format (each vessel was attributed a code) by the Directorate-General for Natural Resources, 148 Safety and Maritime Services (DGRM). 
150 Previous studies on spatial distribution of fish assemblages off the Portuguese continental

151 shelf, based on the analysis of trawl surveys (25), demonstrated the existence of two main

152 biological regions, separated by a boundary located around the Nazaré Canyon, a steep-side

153 valley that represents not only a physical obstacle for fish communities but also separates

154 areas that are geologically and environmentally different. The southern continental shelf is narrow and affected by weak outward winds, while the northern shelf is wider and is influenced by southward coast winds, creating the conditions for upwelling and higher primary production and leading to higher pelagic fish abundance $(26,27)$. This boundary was considered in the present study, using the landing port to associate the fishing activity to a region, north or south, in relation to the Nazaré canyon.

Two variables related with time were considered as possibly influencing LPUE, year (2012 to 2016) and season (winter from January to March (1 - 3), spring from April to June $(4-6)$; summer from July to September (7 - 9) and fall from October to December (10 - 12)).

An environmental variable was included, the North Atlantic Oscillation (NAO) index. This index is related to the difference between low atmospheric pressure at high latitudes and high atmospheric pressure at low latitudes in the North Atlantic and its magnitude depends on the choice of the sampling sites where high and low atmospheric pressures are measured, as well as on the seasons considered (28). In this work we used the NAO index proposed by Hurrell (1995) that considers the difference of normalized sea level pressure between the Azores (high) and Iceland (low). The NAO influences the direction and strength of western winds, and high index values during the previous winter may have a positive effect on primary production $(30,31)$, positively affecting zooplankton abundance and favouring larval survival and fish recruitment $(32,33)$. A time-lag ( $\delta$ in years) was considered for each species, calculated as the number of years between larval phase and recruitment to fisheries; the LPUE of a given year material). 
177 Detailed information on fishing effort was not available for the fleet of interest. However, 178 Portuguese fishing regulations, Ordinance $n^{\circ} 1102-H / 2000$, defines, for vessels larger than 9 179 meters in length overall (LoA), six vessel size categories, with corresponding maximum 180 numbers of gears, where vessels with higher length overall (LoA) are allowed 2 to 3 times 181 higher fishing effort due to longer fleets and more traps. Thus, vessel length was considered a proxy for fishing capacity. A second indicator is the engine power, commonly used to standardize fishing effort in trawlers (20). These two potential indicators of the vessel's fishing capacity (length overall and engine power) were investigated through their correlation with landed weight. A stronger relationship was present between LoA and landed weight (deviance explained was $6.24 \%$ for LoA and $0.13 \%$ for horsepower).

Daily landings per unit of effort $\left(\operatorname{LPUE}_{s, d}\right)$ for each species was calculated through equation 1 :

$$
L P U E_{s, d}=\frac{\sum^{v} W_{s, d, v}}{\sum^{v} L o A_{s, d, v}}
$$
where the landed weight ( $W$; kilograms) for species $s$, day $d$ and vessel $v$, is summed for all vessels for which landings for those species were equal or higher than $10 \%$ of the total landings of that vessel and divided by the sum of the vessel LoA (meters).

\section{Statistical methods}

192 General linear models were used in this study to evaluate the influence of multiple variables on LPUE. Those relationships have been used in this context to establish causal relationships and predicting future outcomes (34).

The variables used in the statistical analysis were: LPUE per day and species as response variable; year and NAO index as continuous explanatory variables; and region and season as categorical explanatory variables.

The $\log _{10}($ LPUE) was the response variable for the model: 


$$
\log _{10}(\text { LPUE })=\beta_{0}+\beta_{Y} Y+\beta_{S} S+\beta_{X} X+\beta_{R} R+\varepsilon
$$

201 where $Y$ the YEAR, $S$ is SEASON, $X$ the NAO INDEX, $R$ the REGION and $\varepsilon$ the associated error, 202 and LPUE for each species is in kg per meter boat length per day.

203 The model was adjusted for each of the 48 species selected. The p-values of the specific 204 terms of the model, with a Bonferroni correction for multiple tests, were used to assess 205 statistical significance and strength of the explanatory variables (35). Significance was discussed only for more important variables with p-values less than 0.01 .

207 Database setup and statistical analysis were carried out using R version 3.6.3 on RStudio.

\section{Mapping LPUE}

209 Maps of fishing abundance were obtained for a number of selected species, using QGIS

210 version 3.10. Daily landings of a particular species and vessel were assigned a trip trajectory

211 by dividing the landed weight for that species by the number of corresponding VMS records 212 of that trip. In this process, only VMS records with speeds equal or below 3.5 knots were

213 considered, assumed to be unequivocally associated to gear haul-up, based on existing 214 knowledge on the operation practices in the coastal multi-gear fleet and the analysis of the 215 frequency distribution of speed records.

216 Global LPUE heatmaps were thus obtained for each species. A global map of all VMS points 217 used (all species) was also produced to indicate the area covered in this study. 


\section{RESULTS}

220 The three most important species for the fleet analysed and the period considered, both in

221 quantity and landed value are the common octopus, the black scabbardfish and the European

222 hake, representing $50 \%$ of the landings. However, while the two former species are almost

223 exclusively landed by the multi-gear fleet, the European hake is mostly landed by coastal

224 trawlers, the landings for multi-gear fleet representing only $40 \%$ of the landed weight for this

225 species, and furthermore is subject to formal assessment. Therefore, it will not be analysed here. The next group of species, by order of importance of the landings in weight, are Atlantic horse mackerel, pouting, surf clam, European conger, swordfish, thornback ray and blue shark, altogether comprising around $27 \%$ of the total landings. In value, again by order of importance, the species ranking four to ten and representing $25 \%$ of the revenue are swordfish, common sole, surf clam, John dory, pouting, angler and European conger. Data with total landings in weight and value, ranks and relative importance are presented as supplementary material (Table 2A).

The five species with higher median LPUE (more than $20 \mathrm{~kg} \mathrm{LoA}^{-1}$ trip $^{-1}$ ) are, by decreasing order, black scabbardfish, surf clam, swordfish, Atlantic pomfret and smooth clam. Data with indicator of the distribution are presented as supplementary material (Table $3 \mathrm{~A}$ ).

The spatial distribution of the fishing activity for vessels where VMS data was available is represented in Figure 1 (the blue area is obtained by marking the VMS points identified as fishing activity).

Figure 1. Spatial distribution of the fishing intensity of the multi-gear coastal fleet from 2012 to 2016 in mainland Portugal. Main fishing ports are indicated as well as the 6 nautical miles line (inner limit of trawling activity). Plotted pings of speeds below $3,5 \mathrm{kt}$, associated with fishing activity. 
243 The fishing activity extends along the entire coast until the 500 metres isobath, with particular

244 intensity to the north of the Nazaré canyon, where the continental shelf is more extended.

245 Between Nazaré and Setúbal canyons, the bottom is characterized by numerous

246 physiographic features (the Central Portuguese submarine canyons, Nazaré, Cascais and

247 Setúbal - Lisbon canyons, Lastras et al., 2009). In these regions, there are multiple rocky

248 areas where trawls can hardly operate, opening the opportunity for fixed gears outside the 6

$249 \mathrm{~nm}$. South of Sesimbra and along the south coast, most of the multi-gear fleet activity is inside

250 the $250 \mathrm{~m}$ isobath. This is related to the intense exploitation of the continental slope by trawlers

251 targeting mostly deep-water crustaceans. All along the coast, narrow strips following the 1000

$252 \mathrm{~m}$ isobath (north of Sesimbra) and the $1500 \mathrm{~m}$ isobath (between Sesimbra and Sagres) and

253 along canyons, constitute the fishing grounds for longline fisheries targeting mostly

254 blackscabbard fish.

255 The results of the linear model applied to the variables YEAR, NAO INDEX, SEASON and REGION are presented in Table 1, for each of the 48 species considered, including the coefficients for the continuous variables (YEAR and NAO INDEX) and the indication of the level of each factor

258 (SEASON and REGION) with higher LPUE. Overall, the two explanatory variables that showed a 259 higher number of significant correlations were SEASON (41 species) and REGION (40 species).

260 Three bivalve species were only present in the southern region, making region relevant for 43

261 of the 48 species considered.

262 A total of 18 species presented yearly trends in the period in study, of which 4 showed a 263 positive and 14 a negative trend. NAO INDEX was significant for 3 species: European hake, whiting and cuttlefish. 
Table 1. Results of the linear model for each of the 48 species considered, with year, NAO, season and region respective coefficients and Bonferroni adjusted p-values. The species are sorted by alphabetic order of their common names inside each taxonomic class. Only $p$-values <0.001 were considered significant. Season and region codes: FA - fall, SP - spring, WI - winter, SU - summer and N - north, S - south respectively.

\begin{tabular}{|c|c|c|c|c|c|c|c|c|c|c|}
\hline Common name & Scientific name & $\begin{array}{l}\text { FAO } \\
\text { code }\end{array}$ & $\begin{array}{l}\text { Year } \\
\text { coef. }\end{array}$ & $\begin{array}{c}\text { Year } \\
\text { p-value }\end{array}$ & Season & $\begin{array}{l}\text { Season } \\
\text { p-value }\end{array}$ & $\begin{array}{l}\text { NAO } \\
\text { coef. }\end{array}$ & $\begin{array}{c}\text { NAO } \\
p-\text {-value }\end{array}$ & Region & $\begin{array}{l}\text { Region } \\
\text { p-value }\end{array}$ \\
\hline \multicolumn{11}{|l|}{ Actinopterygii } \\
\hline Angler & Lophius piscatorius & MON & -0.06 & $<0.0001$ & SP & $<0.0001$ & & $\sim 1.0000$ & $\mathbf{S}$ & $<0.0001$ \\
\hline Atlantic horse mackerel & Trachurus trachurus & HOM & & $\sim 1.0000$ & WI & $<0.0001$ & & $\sim 1.0000$ & $\mathbf{N}$ & $<0.0001$ \\
\hline Atlantic mackerel & Scomber scombrus & MAC & & 0.1784 & & $\sim 1.0000$ & & $\sim 1.0000$ & $\mathbf{N}$ & $<0.0001$ \\
\hline Atlantic pomfret & Brama brama & POA & -0.54 & $<0.0001$ & WI & $<0.0001$ & & $\sim 1.0000$ & $\mathbf{S}$ & 0.0001 \\
\hline Axillary seabream & Pagellus acarne & SBA & -0.03 & $<0.0001$ & FA & $<0.0001$ & & 0.0180 & $\mathbf{S}$ & $<0.0001$ \\
\hline Black scabbardfish & Aphanopus carbo & BSF & & $\sim 1.0000$ & WI & $<0.0001$ & & $\sim 1.0000$ & $\mathbf{S}$ & $<0.0001$ \\
\hline Blackbellied angler & Lophius budegassa & ANK & -0.05 & $<0.0001$ & FA & $<0.0001$ & & $\sim 1.0000$ & $\mathbf{S}$ & $<0.0001$ \\
\hline Blackbelly rosefish & Helicolenus dactylopterus & BRF & & $\sim 1.0000$ & SP & $<0.0001$ & & $\sim 1.0000$ & $\mathbf{S}$ & $<0.0001$ \\
\hline Blackspot seabream & Pagellus bogaraveo & SBR & & 0.0283 & WI & $<0.0001$ & & $\sim 1.0000$ & $\mathbf{S}$ & $<0.0001$ \\
\hline Chub mackerel & Scomber japonicus & MAS & -0.09 & $<0.0001$ & SU & $<0.0001$ & & $\sim 1.0000$ & $\mathbf{N}$ & 0.0001 \\
\hline Common sole & Solea solea & SOL & & 0.1063 & WI & $<0.0001$ & & 0.1407 & $\mathbf{N}$ & $<0.0001$ \\
\hline Common two-banded seabream & Diplodus vulgaris & CTB & & $\sim 1.0000$ & FA & $<0.0001$ & & $\sim 1.0000$ & $\mathbf{S}$ & $<0.0001$ \\
\hline European conger & Conger conger & COE & & $\sim 1.0000$ & SU & $<0.0001$ & & $\sim 1.0000$ & $\mathbf{S}$ & $<0.0001$ \\
\hline European hake & Merluccius merluccius & HKE & & 0.0075 & SU & $<0.0001$ & & 0.0041 & & $\sim 1.0000$ \\
\hline European seabass & Dicentrarchus labrax & BSS & & $\sim 1.0000$ & WI & $<0.0001$ & & 0.5336 & $\mathbf{S}$ & $<0.0001$ \\
\hline John dory & Zeus faber & JOD & -0.04 & $<0.0001$ & SU & $<0.0001$ & & 0.4816 & $\mathbf{S}$ & $<0.0001$ \\
\hline Large-scaled gurnard & Lepidotrigla cavillone & LDV & & 0.7428 & WI & $<0.0001$ & & $\sim 1.0000$ & $\mathbf{N}$ & $<0.0001$ \\
\hline Meagre & Argyrosomus regius & MGR & & $\sim 1.0000$ & FA & $<0.0001$ & & 0.8065 & $\mathbf{S}$ & $<0.0001$ \\
\hline Pouting & Trisopterus Iuscus & $\mathrm{BIB}$ & & 0.1422 & SU & $<0.0001$ & & $\sim 1.0000$ & $\mathbf{N}$ & $<0.0001$ \\
\hline Red gurnard & Aspitrigla cuculus & GUR & & 1.0000 & WI & $<0.0001$ & & $\sim 1.0000$ & $\mathbf{S}$ & $<0.0001$ \\
\hline Red porgy & Pagrus pagrus & RPG & & 0.6288 & FA & $<0.0001$ & & $\sim 1.0000$ & $\mathbf{S}$ & $<0.0001$ \\
\hline Sand sole & Pegusa lascaris & SOS & -0.06 & $<0.0001$ & SP & $<0.0001$ & & $\sim 1.0000$ & $\mathbf{S}$ & $<0.0001$ \\
\hline Silver scabbardfish & Lepidopus caudatus & SFS & 0.09 & 0.0002 & & $\sim 1.0000$ & & $\sim 1.0000$ & $\mathbf{S}$ & $<0.0001$ \\
\hline Surmullet & Mullus surmuletus & MUR & & 0.7390 & FA & $<0.0001$ & & $\sim 1.0000$ & $\mathbf{S}$ & $<0.0001$ \\
\hline Swordfish & Xiphias gladius & SWO & & 0.6247 & FA & $<0.0001$ & & $\sim 1.0000$ & $\mathbf{S}$ & $<0.0001$ \\
\hline Tub gurnard & Chelidonichthys Iucerna & GUU & & 0.8692 & WI & $<0.0001$ & & $\sim 1.0000$ & $\mathbf{N}$ & $<0.0001$ \\
\hline Wedge sole & Dicologlossa cuneata & CET & & $\sim 1.0000$ & SU & $<0.0001$ & & $\sim 1.0000$ & $\mathbf{N}$ & $<0.0001$ \\
\hline Whiting & Merlangius merlangus & WHG & -0.06 & $<0.0001$ & FA & $<0.0001$ & & 0.0025 & $\mathbf{N}$ & $<0.0001$ \\
\hline Wreckfish & Polyprion americanus & WRF & -0.07 & $<0.0001$ & SU & $<0.0001$ & & 0.7327 & $\mathbf{S}$ & $<0.0001$ \\
\hline
\end{tabular}


Table 1. Results of the linear model for each of the 48 species considered, with year, NAO, season and region respective coefficients and Bonferroni adjusted p-values. The species are sorted by alphabetic order of their common names inside each taxonomic class. Only $p$-values <0.001 were considered significant. Season and region codes: FA - fall, SP - spring, WI - winter, SU - summer and N - north, S - south respectively.

\begin{tabular}{|c|c|c|c|c|c|c|c|c|c|c|}
\hline Common name & Scientific name & $\begin{array}{l}\text { FAO } \\
\text { code }\end{array}$ & $\begin{array}{l}\text { Year } \\
\text { coef. }\end{array}$ & $\begin{array}{c}\text { Year } \\
\text { p-value }\end{array}$ & Season & $\begin{array}{l}\text { Season } \\
\text { p-value }\end{array}$ & $\begin{array}{l}\text { NAO } \\
\text { coef. }\end{array}$ & $\begin{array}{c}\text { NAO } \\
\text { p-value }\end{array}$ & Region & $\begin{array}{l}\text { Region } \\
\text { p-value }\end{array}$ \\
\hline \multicolumn{11}{|l|}{ Chondrichthyes } \\
\hline Blonde ray & Raja brachyura & $\mathrm{RJH}$ & -0.06 & $<0.0001$ & SU & $<0.0001$ & & $\sim 1.0000$ & $\mathbf{S}$ & $<0.0001$ \\
\hline Blue shark & Prionace glauca & $\mathrm{BSH}$ & & $\sim 1.0000$ & & 0.0047 & & $\sim 1.0000$ & $\mathbf{S}$ & $<0.0001$ \\
\hline Lowfin gulper shark & Centrophorus lusitanicus & $\mathrm{CPL}$ & & 0.0901 & SU & $<0.0001$ & & $\sim 1.0000$ & $\mathbf{N}$ & $<0.0001$ \\
\hline Nursehound & Scyliorhinus stellaris & SYT & & $\sim 1.0000$ & SP & $<0.0001$ & & $\sim 1.0000$ & $\mathbf{S}$ & $<0.0001$ \\
\hline Shortfin mako & Isurus oxyrinchus & SMA & -0.19 & $<0.0001$ & FA & $<0.0001$ & & $\sim 1.0000$ & $\mathbf{S}$ & $<0.0001$ \\
\hline Smooth-hound & Mustelus mustelus & SMD & & $\sim 1.0000$ & & 0.2634 & & 0.0117 & $\mathbf{S}$ & $<0.0001$ \\
\hline Spotted ray & Raja montagui & RJM & -0.03 & $<0.0001$ & WI & $<0.0001$ & & $\sim 1.0000$ & & $\sim 1.0000$ \\
\hline Thornback ray & Raja clavata & RJC & & $\sim 1.0000$ & SU & $<0.0001$ & & $\sim 1.0000$ & $\mathbf{N}$ & $<0.0001$ \\
\hline Tope Shark & Galeorhinus galeus & GAG & & $\sim 1.0000$ & & $\sim 1.0000$ & & $\sim 1.0000$ & & 0.2906 \\
\hline \multicolumn{11}{|l|}{ Cephalopoda } \\
\hline Common octopus & Octopus vulgaris & OCC & & 0.9520 & FA & $<0.0001$ & & $\sim 1.0000$ & & 0.3171 \\
\hline Cuttlefish & Sepia officinalis & CTC & & $\sim 1.0000$ & WI & $<0.0001$ & 0.07 & $<0.0001$ & $\mathbf{S}$ & $<0.0001$ \\
\hline Neon flying squid & Ommastrephes bartramii & OFJ & & 0.0032 & SU & $<0.0001$ & & $\sim 1.0000$ & $\mathbf{N}$ & $<0.0001$ \\
\hline \multicolumn{11}{|l|}{ Bivalves } \\
\hline Bean clams & Donax spp & DON & & 0.0403 & & 0.5642 & & $\sim 1.0000$ & & \\
\hline Pod razor & Ensis siliqua & EQI & 0.18 & $<0.0001$ & & 0.1393 & & 0.0310 & & \\
\hline Stripped Venus clam & Chamelea gallina & SVE & & 0.3698 & SP & $<0.0001$ & & $\sim 1.0000$ & & $\sim 1.0000$ \\
\hline Surf clam & Spisula solida & ULO & 0.11 & $<0.0001$ & FA & $<0.0001$ & & 0.7979 & $\mathbf{N}$ & $<0.0001$ \\
\hline
\end{tabular}


269 A total of 31 species were analysed in the Actinopterygii class. Except for the European hake,

270 all species presented regional differences with respect to LPUE. Nine species had significantly

271 higher LPUE in the north (Atlantic horse mackerel, Atlantic mackerel, chub mackerel, common

272 sole, large-scaled gurnard, pouting, tub gurnard, wedge sole and whiting), while for the

273 remaining species LPUE was significantly higher in the south. Twelve species displayed

274 significant interannual variations, 10 of which with negative and two with positive coefficients.

275 The former group comprised angler, Atlantic pomfret, axillary bream, blackbelly angler, chub

276 mackerel, forkbeard, John Dory, sand sole, whiting and wreckfish while, in the latter, silver

277 scabbardfish were included. Seasonal variations were significant for a total of 28 species, with

278 higher LPUEs during the winter for nine (Atlantic horse mackerel, Atlantic pomfret, black

279 scabbardfish, blackspot seabream, common sole, European seabass, large-scaled gurnard,

280 red gurnard and tub gurnard), during the spring for four species (angler, blackbelly rosefish,

281 forkbeard and sand sole), during the summer for seven species (chub mackerel, European

282 conger, European hake, John dory, pouting, wedge sole and wreckfish) and during the fall for

283 the remaining eight species (axillary seabream, blackbellied angler, common two-banded

284 seabream, meagre, red porgy, surmullet, swordfish and whiting). The NAO index was

285 significant for European hake and whiting.

286 In the Chondrichthyes class, season was significant for seven out of the nine species analysed:

287 blonde ray, blue shark, lowfin gulper shark, thornback ray (LPUE significantly higher in the

288 summer), nursehound (in the spring), shortfin mako (in the fall) and spotted ray (in the winter).

289 Geographic differences were detected for seven species, two with higher LPUE in the north,

290 lowfin gulper and thornback ray, while the remaining five species, blonde ray, blue shark,

291 nursehound, shortfin mako and smooth-hound, with higher values in the south. A negative

292 trend over time was significant for three species, shortfin mako, blonde ray, and spotted ray.

293 One species, the tope shark did not show any significant association with the explanatory

294 variables in the model. 
295 Season was significant for the three cephalopod species in analysis, the common octopus,

296 the cuttlefish, and the neon flying squid, with higher LPUE in the fall, winter and summer,

297 respectively. Regional differences were significant for cuttlefish and neon flying squid, the first

298 more abundant in the north and the later in the south. Inter-annual variations were significant

299 and with a negative trend for the neon flying squid. For cuttlefish, the correlation between

300 LPUE and the NAO index was significant and positive.

301 Of the five bivalve species, bean, pod razor and smooth clams were exclusively landed in the south, while regional differences were detected for surf clam, with higher LPUEs in the north.

303 Pod razor and surf clam presented an increasing interannual trend, while seasonal patterns

304 were present for the smooth and surf clams, with higher LPUE in the fall, and for the stripped

305 Venus clam, with higher LPUE in the spring. The bean clam did not show any significant 306 correlation although region is implicitly important since this species was caught only in the 307 south.

308 The interpretation of the significance for the important explanatory variables used in the linear model (NAO index excluded) can be visualized in Figure 2. Year and season are compounded in the variable time (represented in the $\mathrm{x}$ axis) and region is taken into consideration by plotting

311 for north and south separately. From the large number of species in analysis, only eight 312 species were selected to be examined in detail. All of these species are almost exclusively 313 targeted by the multi-gear fleet, and none are subjected to formal assessment, being good 314 candidates for the approach proposed in this work. Three are among the ten most important 315 in quantity and/or value and are almost exclusively captured by the multi-gear fleet: black scabbardfish, common sole and common octopus. The blackbellied angler, forkbeard, the 317 wreckfish and the cuttlefish are important caught species for specific segments of the multi318 gear fleet. The shortfin mako is a threatened species with no formal assessment. 
320 Figure 2. Daily landings per unit of effort (kg LoA-1 trip-1) expressed as moving average (MA) of 44

321 days (centre of classes plotted) for each species. The $p$-value of the linear trend in indicated at the top

322 left corner of each plot. Blue and red lines correspond to the south and north regions, respectively.

323 Species: a) black scabbardfish, b) blackbellied angler, c) common sole, d) forkbeard, e) wreckfish, f)

324 shortfin mako, g) common octopus and h) cuttlefish. 
326 Distribution maps of abundance (indicated by LPUE), based on landings and VMS fishing

327 records, were produced for four of the previous species: blackbellied angler, forkbeard, 328 shortfin mako and wreckfish (Figure 3).

Figure 3. Heatmaps of abundance, using LPUE (kg LoA-1 trip-1) as a proxy, from 2012 to 2016 for a total of 4 species: a) forkbeard, b) blackbellied angler, c) wreckfish and d) shortfin mako. Main fishing ports are indicated as well as the 6 nautical miles line (inner limit of trawling activity).

The black scabbardfish is the second most important species landed. It is exclusively landed in the port of Sesimbra, being associated to the south area and despite significant higher average CPUE in the winter, it does not show clear seasonal fluctuations (Figure 2a). The blackbellied angler, with a significant reduction of LPUE over time, shows different trends in the north and south regions. The negative trend can be attributed to a significant drop in LPUE in the north after 2014 but, in the south, LPUE stayed stable (Figure 2b). For the south region, where seasonal fluctuations are clearer, there are two peaks in the spring and fall, this last one with higher average LPUE. The fishing effort for the blackbellied angler concentrates off Cascais and Pencihe while higher LPUEs are located in the Sesimbra-Sagres coast, at fishing depths between 100 and 250 meters (Figure 3a). The common sole, with significant higher LPUE in the north, displays very similar patterns with respect to season in both areas (Figure 2c), likely due to migration patterns of the species. The forkbeard, landed mainly in the south, shows a significant decreasing trend with time as evidenced in Figure 3d. Superimposed on this trend, seasonal variations can be observed, with hight average values in the spring but

347 with peaks in early summer during most of the period in analysis. The LPUE suggests two 348 hotspots, one North of the Nazaré canyon and a second between Cascais and Peniche (Figure $3 b)$. Both areas are at $250 \mathrm{~m}$ depth, close to the continental slope. The wreckfish also shows a decaying trend over time with a superimposed seasonal cycle, with higher LPUE in the summer (Figure 2e). It is also a species mostly captured in the south and is mainly concentrated in three hotspots, two off Sagres at around $250-500 \mathrm{~m}$ depth and the third in the 
353 central region in the upper slope at depths around 500m depth (Figure 3c). A less dense area

354 can be observed in the canyon off Nazaré.

355 The shortfin mako displays a distribution showing a very marked reduction 2014 onwards

356 (Figure 2f). This protected species cannot be targeted, and the reduction may be the result of

357 a landing ban, not necessarily a reduction in its capture. It is distributed in the central

358 continental slope.

359 The two cephalopods, common octopus and cuttlefish, display typical seasonal variations

360 related with their yearly lifecycles, with no yearly trends and higher catches in the fall and

361 winter respectively. The cuttlefish has higher LPUE in the south, although in the last two years

362 the values were similar in both regions, and it showed a significant correlation with the NAO

363 index. 


\section{DISCUSSION}

367

The assessment and management of the species caught by the multi-gear fleet analysed here is difficult due to the large number of species (near three hundred). A simple methodology that allows the temporal and special monitoring of these resources and provides information that can be used in management is very useful, as observed in other studies with similar objectives (37).

The index capture per unit of effort (CPUE) was one of the first indicators of abundance (biomass) of a resource used in stock assessment (38), under the assumption that CPUE is linearly correlated with stock biomass and may therefore be used as its indicator. The most common phenomena affecting the proportionality between CPUE and biomass, that may invalidate its use as an indicator of biomass is hyperstability (39), which is likely to occur when fishing in areas of high concentration of the species, for example spawning aggregations (40). This situation may be combined with searching strategies targeting different concentrations of the species (41), causing CPUE to stay stable even when the resources decline. Other causes include abandonment of the fishery by less skilled fisherman when the stock declines (42) or increase in catchability due to gear improvement of better detection methods (43). The stability of the fleet in the present study, with a tendency to maintain the number of vessels and the gears used. along with the short period analyzed, contributes to reducing the probability of the referred factors to play a major role in changes in the CPUE - abundance relationship.

Accurate estimation of the fishing effort was not possible, since finer measures of effort based on the gear characteristics (i.e., net length, number of hooks or traps or soaking time) were not available. Thus, vessel length was used to standardize fishing effort. Vessel length is an indicator that reflects the fishing capacity since there is an association between vessel's length and the maximum fleet size (number of net panels or hooks) it is allowed to operate.

In this study CPUE was replaced by LPUE, assuming that catch and landings do not differ substantially due to low levels of discards. Of the different gears used by the multi-gear fleet 
392 the most important are longlines, tangling and trammel nets, and pots. Studies in discards are

393 available for the Portuguese continental coast for trammel nets and pelagic longlines. For

394 trammel nets, (44-47) indicate chub mackerel (Scomber japonicus), sardine (Sardina

395 pilchardus) and longspine snipefish (Macroramphosus scolopax) as the most discarded

396 species, other species occasionally discarded being longfin gurnard (Chelidonichthys

397 obscura), dragonet (Callioynimus lyra) and bull ray (Pteromylaeus bovines). For the pelagic

longline (Coelho et al. 2005) the discarded species were smooth lanternshark (Etmopterus pusillus), lesser-spotted dogfish (Scyliorhinus canicula), rays (Raja spp) and rabbit fish

400 (Chimaera monstrosa). In any case, discards were almost entirely reported for species with no commercial value. Only two of these belong to the 48 selected species in this work, the chub mackerel and unspecified rays, invalidating the use of LPUE as an index of abundance in these cases. For all the other species, the assumption can be made that LPUE can replace CPUE as an indicator of abundance.

One last important issue related to the use of global indicators of abundance such as CPUE or LPUE is the assumption that catches are a random sample of the total range of distribution of the species, meaning no selection of specific fishing grounds or areas with high density (48). This is not the case in this study, but the combination of LPUE with location (based on VMS data) can overcome this limitation allowing a spatial interpretation of CPUE.

The reason for black scabbardfish, surf clam, swordfish, Atlantic pomfret and smooth clam

411 having higher median values of $\operatorname{LPUE}\left(53.5,27.5,21.9,21.2\right.$ and $20.2 \mathrm{~kg} \mathrm{LoA}^{-1}$ trip $^{-1}$ 412 respectively) can be explained due to the characteristics of the fishing and the way the LPUE 413 index was built. Besides fishing operations resulting in high catches, LPUE are favoured by 414 longer trips or smaller vessels. The black scabbardfish (with median LPUE above 50) is 415 targeted by a highly efficient deep bottom longline fishery with daily trips. The swordfish is 416 caught by drifting longlines in trips that last for several days (typically three weeks; Campos et 417 al., 2019). The Atlantic pomfret was reported as being the by-catch of a longline fishery 
418 targeting hake (50) but no updated information on the possibility of this species being targeted

419 is available, justifying specific studies. The two bivalve species have high median LPUE

420 because they have individual daily quotas (in the order of hundreds of $\mathrm{Kg}$ ) and the vessels

421 have low LoA. The LPUE as expressed in this work is not a good indicator of the abundance

422 of bivalve species due to the individual daily quota system.

423 The results of the linear models for LPUE as a function of year, NAO INDEX, REGION and 424 SEASON, applied to the 48 most important species, showed a wide range of significant factors, indicating that a management strategy common to the whole fleet would be very difficult to apply. One clear output is the need to consider region when implementing management actions. In this study two regions were considered, north and south, separated by the Nazaré canyon on the west coast. While ubiquitous specie such as the common octopus showed an even distribution throughout both regions, most species were strongly associated with the north or south areas, with southern species (lowfin gulper shark, shortfin mako, black scabbardfish, forkbeard, silver scabbardfish, swordfish and wreckfish) opposed to Northern ones (surf clam and neon flying squid).

Regarding the 41 species for which significant seasonal variation was estimated, all eight selected species for further graphical analysis showed higher LPUEs towards specific seasons. In some cases, abundance patterns of one species may be related to another species, as it is the case of the common sole and the cuttlefish which are mostly caught

437 together. While the cuttlefish spawns in inshore waters and migrates to offshore waters ( 6 $\mathrm{nm}$ ) during autumn and winter for growing purposes (51), the common sole spawns and grows during 2 years in on-shore nurseries until moving to deeper waters from summer to autumn

440 (52). Since the fleet's fishing grounds for these species concentrate around the 200 meters 441 depth, which is the maximum depth distribution of both species, our findings suggest that 442 higher availability to fisheries during the winter periods cause higher LPUE. The blackbellied 443 angler also shows a distinctive seasonal pattern in LPUE with a steep decrease in the autumn 
444 period and further decrease in winter. This is attributed to the existence of a fish closure

445 between January and February, comprising the reproduction period, with the purpose to 446 control the stock decline of anglers (Lophius spp.). For the Atlantic wreckfish and the shortfin

447 mako LPUE was found to be significantly higher during the summer and fall respectively.

448 Although caught in different seasons and with different fishing gears, both species are mainly 449 targeted by the same, highly specific, group of vessels operating in the NE Atlantic, that often 450 use seamounts as fishing grounds. While the bottom longline is used during the summer 451 periods to target wreckfish over the seamounts, the use of drifting longlines is higher during 452 fall to mainly target swordfish, capturing also pelagic sharks such as shortfin mako. (53). Since 453 wreckfish is a sedentary territorial species and shortfin mako a large pelagic migrator it is here suggested that although wreckfish and shortfin mako are caught all year, a highly specific fleet concentrate the effort during the summer and fall seasons. Due to this, when managing the wreckfish fisheries, the difference between the coastal and seamounts fleets should be considered. The black scabbardfish shows higher LPUE levels on the winter periods. Although little is known about the life cycle of this deep water species, it is suggested that they undergo migration from the West British Isles growing grounds to lower latitudes for reproduction purposes (54). The higher LPUE associated to winter, which was also suggested in previous studies about this fleet, is yet to be explained (55). Finally, the forkbeard is mainly captured by the bottom longline fleet that targets more commercially exploited species such as blackbelly rosefish, blackspot seabream, red porgy and silver scabbardfish. Although little is known about its life cycle, the slower growth rates match higher LPUE during spring (56). At first, this could indicate that species undergo migration away from feeding grounds and increase its availability to fisheries, nevertheless it's seasonal variability should be carefully considered due to not being a main target species. 
470 statistically significant, most of these trends have little practical impact since the absolute value

471 of the slope, for log(LPUE) as a function of year, is close to zero (for 14 species less than 0.1 ).

472 Such a result is expected given the short period considered. For some species, landings were

473 found to be restricted to some years, as it is the case of the sharks (lowfin gulper shark and

474 shortfin mako), landed mostly from 2012 to 2014, with minor landings in subsequent years.

475 For other species, such as neon flying squid and silver scabbardfish, peaks were registered in LPUE in 2016 and 2014-2015, respectively.

477 Only three species showed a significant correlation between NAO index and species relative 478 abundance, cuttlefish, whiting and European hake. European hake is not considered in the 479 context of this work because it is mainly landed by coastal trawlers. With respect to cuttlefish, 480 a non-significant relationship between the NAO index and the abundance of this species was reported for the Mediterranean Sea (57) but it is know that mollusc growth is influenced by temperature (58), and a positive correlation would be expected given the positive association between higher NAO indices and sea surface temperature (59). A long-term study in the North

484 Sea found no significant correlation between the species abundance and the NAO index (60)

485 but in other studies, positive correlations were found. A correlation between the NAO index 486 (warmer and dryer than average summer conditions) and the mean length of the age-0 group 487 in the following winter was found for the population using the Bristol Channel as a nursery 488 ground (61). A positive corelation with abundance was also found for the population of the 489 Thames estuary (62). Better information of the spatial distribution of nursery grounds would 490 be necessary to understand the possible relationship of the NAO index and whiting abundance 491 off the Portuguese coast.

492 Species such as the common octopus, anglers, black scabbardfish, sole, swordfish and 493 wreckfish are known to be targeted by this multi-gear fleet. Nevertheless, several species 494 addressed in this study are being captured as by-catch. It is the case of the gurnards (tub 495 gurnard C. lucerna, red gurnard A. cuculus and large-scaled gurnard L. cavillone), wedge sole, 

size and skates (spotted ray, thornback ray, and blonde ray), caught in large mesh size nets.

498 Nine of the 48 most important species are Chondrichthyes species, known for their late499 maturity and high longevity associated with high commercial interest which makes them very 500 susceptible to overfishing (63), and two of them, the thornback ray and the blue shark rank 9 501 and 10 in importance due to amounts landed. During the period in study shortfin mako displayed a sharp decrease but this may be due to discarding in recent years. According to ICCAT, this species was reported threatened in the North Atlantic during the period covered in this work due to bycatch of the swordfish fishing fleet (64). Since 2019, the shortfin mako was introduced in the CITES appendix II and in 2020 landings were forbidden in multiple European countries due to decreasing population.

507 Forkbeard, which is mainly caught as bycatch by the longline coastal fleet operating in the 508 southern coast, showed a steep decrease. This is not the case in the north, where landings 509 are lower and constant throughout this period. A population decline was previously considered 510 in 2011-2012 when Atlantic and Mediterranean catches dropped by 50\% (65). The hypothesis 511 of a stock decline starting in 2012 and continuing onward until, at least, 2016, the upper limit 512 of the time range in our data, is plausible. Lastly, wreckfish, which is mainly caught by large 513 longline vessels that operate in the Atlantic seamounts, also showed a decreasing trend during 514 the 6-year period. This fleet mainly shifts between drifting longline, for swordfish, and bottom 515 longline, for demersal species such as wreckfish (53). Current information regarding 516 population trends in abundance indicates a decrease since 2015, particularly in the Azores 517 area (66). Since the wreckfish is a long-living, late maturity species not subject to conservation 518 measures such as minimum conservation reference size (MCRS), quotas and fishing gear 519 restrictions or regular stock assessment, it is particularly vulnerable to over-exploitation. We 520 hereby suggest that a monitoring program to evaluate their weight and length distributions 521 should be carried out. 
522 Although modelling and mapping data are from two different sources, landings and VMS

523 respectively, both are in line with the existence of regional differences in species assemblages.

524 A previous study (25) demonstrated the existence of two fish assemblages separated by the

525 Nazaré canyon, which is in accordance with the results obtained for the majority of the species

526 in our study. Regional differences, evidenced when mapping fishing effort and LPUE, can be

527 used as indicator of changes in the fishing activity or condition of the stocks in a timely manner.

528 Trends in LPUE are a simple approach to characterize fisheries status in multi-species

529 fisheries, where the high number of species involved makes the cost of fisheries independent

530 stock assessment for all exploited species unrealistic. Due to this, when relative abundance

531 through landings or catch data is the only data available, as it is the case for wreckfish,

532 forkbeard, john dory and shortfin mako in this study, these indexes provide the best available

533 information for the implementation of management advice. The combination of LPUE indexes

534 with VMS data, can be used to monitor populations for species where discards are negligible

535 and quota systems do not generate constant LPUE values.

536 The approach used here needs to be expanded by improving the available information namely

537 increasing the length of the time series analysed (to distinguish between random fluctuations

538 and temporal trends) and considering information on migratory and lifecycle patterns (to

539 correctly interpretate the geographical and seasonal changes in LPUE). In this work a

540 simplistic approach with respect to region was considered, with only two zones included in the

541 model. Variations in fleet characteristics and oceanographic conditions, such as depth, may

542 suggest a different partition of the area studied. The influence of the gear type on LPUE and

543 the associations of species caught by each gear also need to be considered, maybe

544 complemented with interviews to the skippers to identify target and by-catch species.

545 In conclusion, it is suggested that the methodology proposed here, consisting in the analysis

546 of LPUE in specific areas over time, as an indicator of the fish condition, will be useful to 
547 monitor fished populations and to provide guidance for management when fisheries

548 independent data are not available.

549

550 ACKNOWLEDGEMENTS

551 This study was carried out at the scope of the project TECPESCAS - Project Mar $202016-$

552 01-04-FMP-0010-IPMA. The fisheries data was supplied to IPMA by the Portuguese

553 Directorate-General for Natural Resources, Safety and Maritime Services (DGRM). 


\section{REFERENCES}

555 1. Bailey N, Campbell N, Holmes S, Needle C, Wright P. Real time closures of fisheries. Dir Int policies, policy Dep B Struct Cohes policies Fish Eur Parliam. 2010;

2. European Union. Regulation (EU) No $1380 / 2013$ of the European Parliament and of the Council. Official Journal of the European Union. Strasbourg; 2013.

3. Thoya P, Maina J, Möllmann C, Schiele KS. AIS and VMS Ensemble Can Address Data Gaps on Fisheries for Marine Spatial Planning. Sustainability [Internet]. 2021 Mar 29;13(7):3769. Available from: https://www.mdpi.com/2071-1050/13/7/3769

4. Druon J, Gascuel D, Gibin M, Zanzi A, Fromentin J, Colloca F, et al. Mesoscale productivity fronts and local fishing opportunities in the European Seas. Fish Fish [Internet]. $2021 \quad$ Jul 4;(May):faf.12585.

Available from: https://onlinelibrary.wiley.com/doi/10.1111/faf.12585

5. Birchenough SE, Cooper PA, Jensen AC. Vessel monitoring systems as a tool for 568 mapping fishing effort for a small inshore fishery operating within a marine protected area. Mar Policy [Internet]. 2021 Feb;124(May 2020):104325. Available from: https://doi.org/10.1016/j.marpol.2020.104325

570

6. ICES. Science Plan. 2019.

571

7. Bradley D, Merrifield M, Miller KM, Lomonico S, Wilson JR, Gleason MG. Opportunities to improve fisheries management through innovative technology and advanced data systems. Fish Fish [Internet]. 2019 May 13;20(3):564-83. Available from: https://onlinelibrary.wiley.com/doi/abs/10.1111/faf.12361

576

577

578

8. Natale F, Carvalho N, Paulrud A. Defining small-scale fisheries in the EU on the basis

9. Anderson ED. The History of Fisheries Management and Scientific Advice - the 
11. Grüss A, Walter JF, Babcock EA, Forrestal FC, Thorson JT, Lauretta M V., et al.

587

588

589

590

591

592

593

594

595

596

597

598

599

600

601

602

603

604

605

606

607

608

609

610

611

612

613

614

615 Evaluation of the impacts of different treatments of spatio-temporal variation in catchper-unit-effort standardization models. Fish Res [Internet]. 2019 May;213(July 2018):75-93. Available from: https://doi.org/10.1016/j.fishres.2019.01.008

12. Harley SJ, Myers RA, Dunn A. Is catch-per-unit-effort proportional to abundance? Can J Fish Aquat Sci [Internet]. 2001;58(9):1760-72. Available from: http://www.nrc.ca/cgibin/cisti/journals/rp/rp2_abst_e?cjfas_f01-112_58_ns_nf_cjfas58-01

13. Maunder MN, Punt AE. Standardizing catch and effort data: a review of recent approaches. Fish Res [Internet]. 2004 Dec;70(2-3):141-59. Available from: https://linkinghub.elsevier.com/retrieve/pii/S0165783604001638

14. Castro J, Garcia D, Cebrian JL, Patiño B. Standardization of hake LPUE series of the Galician set-longline fleet in Subarea VII. Copenhagen,; 2016.

15. Kerby TK, Cheung WWL, van Oosterhout C, Engelhard GH. Entering uncharted waters: Long-term dynamics of two data limited fish species, turbot and brill, in the North Sea. J Sea Res [Internet]. 2013 Nov;84:87-95. Available from: http://dx.doi.org/10.1016/j.seares.2013.07.005

16. Hazen EL, Scales KL, Maxwell SM, Briscoe DK, Welch H, Bograd SJ, et al. A dynamic ocean management tool to reduce bycatch and support sustainable fisheries. Sci Adv. 2018;4(5):1-8.

17. Needle CL, Catarino R. Evaluating the effect of real-time closures on cod targeting. ICES J Mar Sci. 2011;68(8):1647-55.

18. Woods PJ, Elvarsson BP, Sigurdsson T, Stefánsson G. Evaluating the effectiveness of real-time closures for reducing susceptibility of small fish to capture. ICES J Mar Sci. 2018;75(1):298-308.

19. INE. Estatísticas da Pesca - 2019. Lisboa; 2020.

20. EU. Scientific, Technical and Economic Committee for Fisheries (STECF) - Fisheries Dependent -Information - FDI (STECF-20-10). Publ Off Eur Union. 2020;EUR 28359.

21. Erzini K, Costa ME, Bentes L, Borges TC. A comparative study of the species composition of discards from five fisheries from the Algarve (southern Portugal). Fish Manag Ecol [Internet]. 2002 Feb;9(1):31-40. Available from: 
http://doi.wiley.com/10.1046/j.1365-2400.2002.00284.x

617

618

619

620

621

622

623

624

625

626

627

628

629

630

631

632

633

634

635

636

637

638

639

640

641

642

643

644

645

646

647

22. Vasconcelos P, Pereira F, Moreno A, Gaspar MB. Bycatch, discards and survival rates in the small-scale cuttlefish trap fishery on sandy bottoms off the Algarve coast (southern Portugal). Fish Manag Ecol [Internet]. 2019 Aug 27;26(4):334-44. Available from: https://onlinelibrary.wiley.com/doi/abs/10.1111/fme.12364

23. Bordalo-Machado P, Figueiredo I. The fishery for black scabbardfish (Aphanopus carbo Lowe, 1839) in the Portuguese continental slope. Rev Fish Biol Fish [Internet]. 2009 Mar 24;19(1):49-67. Available from: http://link.springer.com/10.1007/s11160-0089089-7

24. Kerby TK, Cheung WWL, van Oosterhout C, Engelhard GH. Entering uncharted waters: Long-term dynamics of two data limited fish species, turbot and brill, in the North Sea. J Sea Res. 2013 Nov;84:87-95.

25. Sousa P, Azevedo M, Gomes MC. Demersal assemblages off Portugal: Mapping, seasonal, and temporal patterns. Fish Res. 2005;75(1-3):120-37.

26. Fiúza AFG. Upwelling Patterns off Portugal. In: Coastal Upwelling Its Sediment Record [Internet]. Boston, MA: Springer US; 1983. p. 85-98. Available from: http://link.springer.com/10.1007/978-1-4615-6651-9_5

27. Cunha M. Physical control of biological processes in a coastal upwelling system: comparison of the effects of coastal topography, river run-off and physical oceanography in the northern and southern parts of the western Portuguese coastal waters. Unpubl Ph D thesis, Univ Lisbon, Port [Internet]. 2002;(November 2002):30. Available from: http://scholar.google.com/scholar?hl=en\&btnG=Search\&q=intitle:Physical+Control+of +Biological+Processes+in+a+Coastal+Upwelling+System+:+Comparison+of+the+Effe cts+of+Coastal+Topography+,+River+Runoff+and+Physical+Oceanography+in+the+Northern+and+Southern+P

28. Ottersen G, Planque B, Belgrano A, Post E, Reid PC, Stenseth NC. Ecological effects of the North Atlantic Oscillation. Oecologia [Internet]. 2001 Jun 1;128(1):1-14. Available from: http://link.springer.com/10.1007/s004420100655

29. Hurrell JW. Decadal Trends in the North Atlantic Oscillation: Regional Temperatures and Precipitation. Science (80- ) [Internet]. 1995 Aug 4;269(5224):676-9. Available from: https://www.sciencemag.org/lookup/doi/10.1126/science.269.5224.676 
648

649

650

651

652

653

654

655

656

657

658

659

660

661

662

663

664

665

666

667

668

669

670

671

672

673

674

675

676

677

678

30. Bode A, Anadón R, Morán X, Nogueira E, Teira E, Varela M. Decadal variability in chlorophyll and primary -production off NW Spain. Clim Res [Internet]. 2011 Aug 30;48(2):293-305. Available from: http://www.int-res.com/abstracts/cr/v48/n2-3/p293$305 /$

31. Ottersen G, Planque B, Belgrano A, Post E, Reid PC, Stenseth NC. Ecological effects of the North Atlantic Oscillation. Oecologia. 2001 Jun;128(1):1-14.

32. Planque B, Fromenti J-M. Calanus and environment in the eastern North Atlantic. I. Spatial and temporal patterns of C. finmarchicus and C. helgolandicus. Mar Ecol Prog Ser. 1996;134:101-9.

33. Solow AR. Fisheries recruitment and the North Atlantic Oscillation. Fish Res [Internet]. 2002 Jan;54(2):295-7. Available from: https://linkinghub.elsevier.com/retrieve/pii/S0165783600003088

34. Farway JJ. Extending the Linear Model with R: Generalized Linear, Mixed Effects and Nonparametric Regression Models. 2nd ed. Taylor \& Francis Group, editor. New York: CRC Press; 2016. 312 p.

35. Armstrong RA. When to use the Bonferroni correction. Ophthalmic Physiol Opt [Internet]. $2014 \quad$ Sep;34(5):502-8. Available from: http://doi.wiley.com/10.1111/opo.12131

36. Lastras G, Arzola RG, Masson DG, Wynn RB, Huvenne VAI, Hühnerbach V, et al. Geomorphology and sedimentary features in the Central Portuguese submarine canyons, Western Iberian margin. Geomorphology [Internet]. 2009 Feb;103(3):310-29. Available from: http://dx.doi.org/10.1016/j.geomorph.2008.06.013

37. Ulman A, Pauly D. Making history count: The shifting baselines of Turkish fisheries. Fish Res [Internet]. 2016 Nov;183:74-9. Available from: http://dx.doi.org/10.1016/j.fishres.2016.05.013

38. Ricker WE. Relation of "Catch per Unit Effort" to Abundance and Rate of Exploitation. J Fish Res Board Canada [Internet]. 1940 Jan 1;5a(1):43-70. Available from: http://www.nrcresearchpress.com/doi/10.1139/f40-008

39. Hilborn R, Walters CJ. Quantitative Fisheries Stock Assessment [Internet]. Boston, MA: Springer US; 1992. Available from: http://link.springer.com/10.1007/978-1-4615-35980 
679

680

681

682

683

684

685

686

687

688

689

690

691

692

693

694

695

696

697

698

699

700

701

702

703

704

705

706

707

708

709

710

40. Erisman BE, Allen LG, Claisse JT, Pondella DJ, Miller EF, Murray JH. The illusion of plenty: hyperstability masks collapses in two recreational fisheries that target fish spawning aggregations. Walters C, editor. Can J Fish Aquat Sci [Internet]. 2011 Oct;68(10):1705-16. Available

from:

http://www.nrcresearchpress.com/doi/10.1139/f2011-090

41. Clark MR, Dunn MR, Anderson OF. Development of estimates of biomass and sustainable catches for orange roughy fisheries in the New Zealand region outside the EEZ: CPUE analyses, and application of the "seamount meta-analysis" approach. New Zeal Fish Assess Rep 2010/19. 2010;(July).

42. van Poorten BT, Walters CJ, Ward HGM. Predicting changes in the catchability coefficient through effort sorting as less skilled fishers exit the fishery during stock declines. Fish Res [Internet]. 2016 Nov;183:379-84. Available from: http://dx.doi.org/10.1016/j.fishres.2016.06.023

43. Walters C, Maguire J-J. Lessons for stock assessment from the northern cod collapse. Rev Fish Biol Fish [Internet]. 1996 Jun;6(2):125-37. Available from: http://link.springer.com/10.1007/BF00182340

44. Batista MI, Teixeira CM, Cabral HN. Catches of target species and bycatches of an artisanal fishery: The case study of a trammel net fishery in the Portuguese coast. Fish

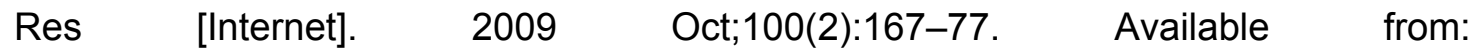
https://linkinghub.elsevier.com/retrieve/pii/S0165783609002033

45. Borges, Erzini, Bentes, Costa, Gonçalves, Lino, et al. By-catch and discarding practices in five Algarve (southern Portugal) métiers. J Appl Ichthyol [Internet]. 2001 Jul 18;17(3):104-14. Available from: https://onlinelibrary.wiley.com/doi/10.1111/j.14390426.2001.00283.x

46. Coelho R, Erzini K, Bentes L, Correia C, Lino PG, Monteiro P, et al. Semi-pelagic Longline and Trammel Net Elasmobranch Catches in Southern Portugal: Catch Composition, Catch Rates and Discards. J Northwest Atl Fish Sci [Internet]. 2005 Mar 2;35(March):531-7. Available from: http://journal.nafo.int/Portals/0/2005/26-coelho.pdf

47. Erzini K, Costa ME, Bentes L, Borges TC. A comparative study of the species composition of discards from five fisheries from the Algarve (southern Portugal). Fish Manag Ecol. 2002 Feb;9(1):31-40.

48. Hilborn R, Walters CJ. Quantitative Fisheries Stock Assessment. Boston, MA: Springer 
US; 1992.

712

713

714

715

716

717

718

719

720

721

722

723

724

725

726

727

728

729

730

731

732

733

734

735

736

737

738

739

740

741

49. Campos A, Lopes P, Fonseca P, Figueiredo I, Henriques V, Gouveia N, et al. Portuguese fisheries in seamounts of Madeira-Tore (NE Atlantic). Mar Policy [Internet]. 2019 Jan;99(September 2018):50-7. Available from: https://doi.org/10.1016/j.marpol.2018.10.005

50. Erzini K, Gonçalves JM., Bentes L, Lino P., Ribeiro J. The hake deepwater semi-pelagic ("pedra-bola") longline fishery in the Algarve (southern Portugal). Fish Res [Internet]. 2001 May;51(2-3):327-36. Available from: https://linkinghub.elsevier.com/retrieve/pii/S0165783601002569

51. Jereb P, Allcock AL, Lefkaditou E, Piatkowski U, Hastie LC, Pierce G. Cephalopod biology and fisheries in Europe: II.Species Accounts. ICES Cooperative Research Report [Internet]. 2015. 360 p. Available from: www.ices.dk

52. ICES. Report of the Working Group for the Bay of Biscay and the Iberian waters Ecoregion (WGBIE) [Internet]. Copenhagen, Denmark; 2015. Available from: http://www.ices.dk/sites/pub/Publication

Reports/Expert

Group Report/acom/2015/WGBIE/01 WGBIE report 2015.pdf

53. Campos A, Lopes P, Fonseca P, Figueiredo I, Henriques V, Gouveia N, et al. Portuguese fisheries in seamounts of Madeira-Tore (NE Atlantic). Mar Policy. 2019 Jan;99(September 2018):50-7.

54. Farias I, Morales-Nin B, Lorance P, Figueiredo I. Black scabbardfish, Aphanopus carbo , in the northeast Atlantic: distribution and hypothetical migratory cycle. Aquat Living Resour [Internet]. 2013 Oct 23;26(4):333-42. Available from: http://www.alrjournal.org/10.1051/alr/2013061

55. Bordalo-machado P, Fernandes AC, Figueiredo I, Moura O, Reis S, Pestana G. The black scabbardfish (Aphanopus carbo Lowe , 1839) fisheries from the Portuguese mainland and Madeira Island. Sci Mar. 2009;73(2):63-76.

56. Vieira AR, Neves A, Sequeira V, Paiva RB, Gordo LS. Age and growth of forkbeard, Phycis phycis, in Portuguese continental waters. J Mar Biol Assoc United Kingdom [Internet]. $2014 \quad$ May 13;94(3):623-30. Available from: https://www.cambridge.org/core/product/identifier/S0025315413001549/type/journal_ article 
57. Keller S, Valls M, Hidalgo M, Quetglas A. Influence of environmental parameters on the life-history and population dynamics of cuttlefish Sepia officinalis in the western Mediterranean. Estuar Coast Shelf Sci [Internet]. 2014 May;145(April):31-40. Available from: https://linkinghub.elsevier.com/retrieve/pii/S0272771414001048

58. Domingues PM, Bettencourt V, Guerra A. Growth of Sepia officinalis in captivity and in nature. Vie Milieu. 2006;56(2):109-20.

59. Báez JC, Gimeno L, Gómez-Gesteira M, Ferri-Yáñez F, Real R. Combined Effects of the North Atlantic Oscillation and the Arctic Oscillation on Sea Surface Temperature in the Alborán Sea. Álvarez I, editor. PLoS One [Internet]. 2013 Apr 18;8(4):e62201. Available from: https://dx.plos.org/10.1371/journal.pone.0062201

60. Kerby TK, Cheung WWL, van Oosterhout C, Engelhard GH. Wondering about wandering whiting: Distribution of North Sea whiting between the 1920s and 2000s. Fish Res [Internet]. 2013 Aug;145:54-65. Available from: http://dx.doi.org/10.1016/j.fishres.2013.02.012

61. Henderson PA. A long-term study of whiting, Merlangius merlangus $(L)$ recruitment and population regulation in the Severn Estuary, UK. J Sea Res [Internet]. 2019 Dec;155(August):101825. Available

from: https://doi.org/10.1016/j.seares.2019.101825

62. Attrill MJ, Power M. Climatic influence on a marine fish assemblage. Nature [Internet]. 2002 May;417(6886):275-8. Available from: http://www.nature.com/articles/417275a

63. Pacoureau N, Rigby CL, Kyne PM, Sherley RB, Winker H, Carlson JK, et al. Half a century of global decline in oceanic sharks and rays. Nature [Internet]. 2021 Jan 28;589(7843):567-71. Available from: http://dx.doi.org/10.1038/s41586-020-03173-9

64. ICCAT. REPORT OF THE 2019 SHORTFIN MAKO SHARK STOCK ASSESSMENT UPDATE MEETING. Madrid; 2019.

65. Garcia S. Phycis phycis [Internet]. The IUCN Red List of Threatened Species 2015: e.T198604A18986739. $2015 . \quad$ Available from: https://www.iucnredlist.org/species/198604/18986739

66. Collette B, Fernandes P, Heessen H, Smith-Vaniz WF. Polyprion americanus. The IUCN Red List of Threatened Species 2015: e.T43972A45795607 [Internet]. The IUCN Red List of Threatened Species 2015. 2015 [cited 2021 Jan 19]. Available from: 
bioRxiv preprint doi: https://doi.org/10.1101/2021.10.04.463092; this version posted October 4, 2021. The copyright holder for this preprint (which was not certified by peer review) is the author/funder, who has granted bioRxiv a license to display the preprint in perpetuity. It is made available under aCC-BY 4.0 International license. 


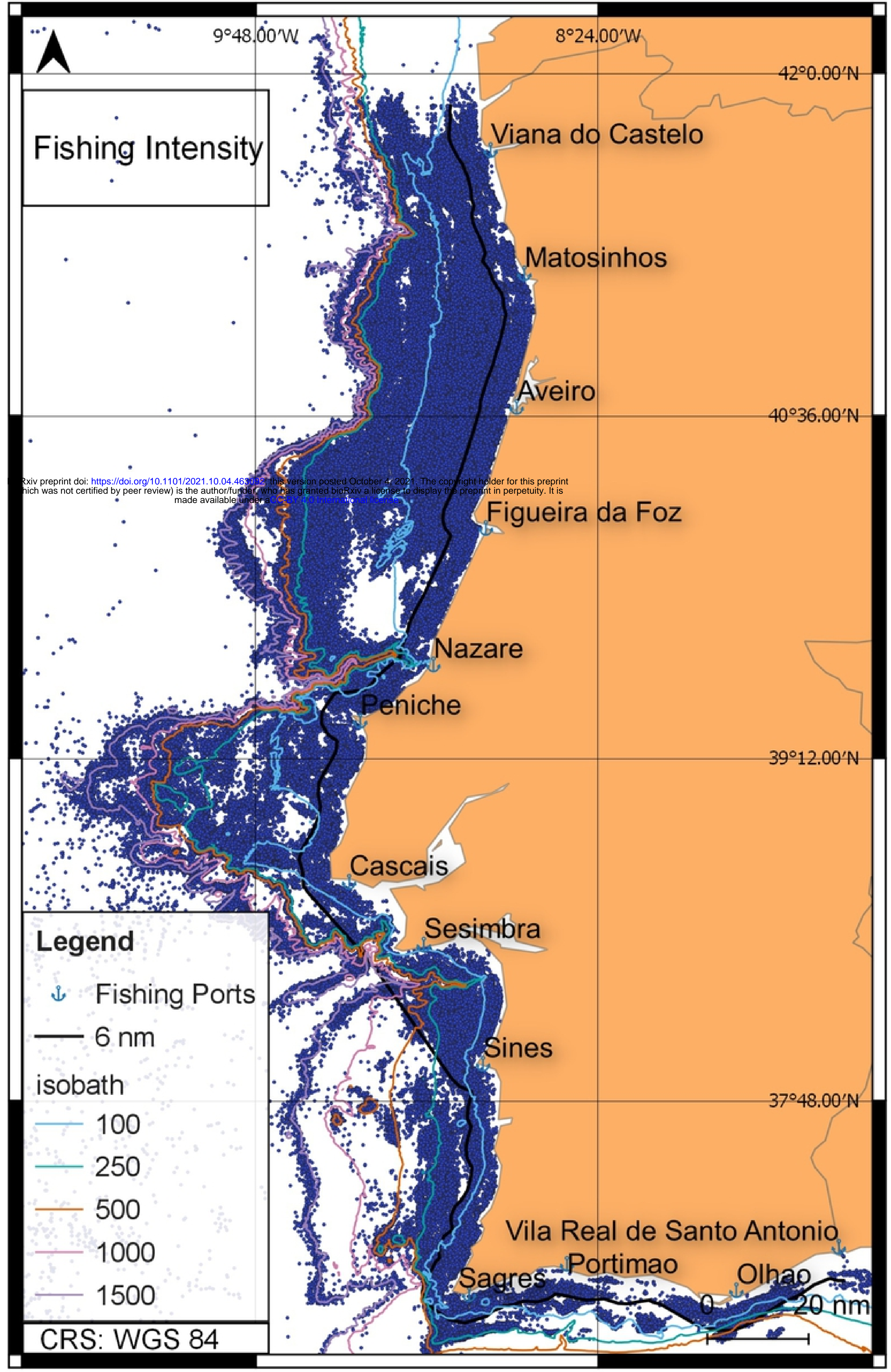

Figure1 
a) BSF - black scabbardfish

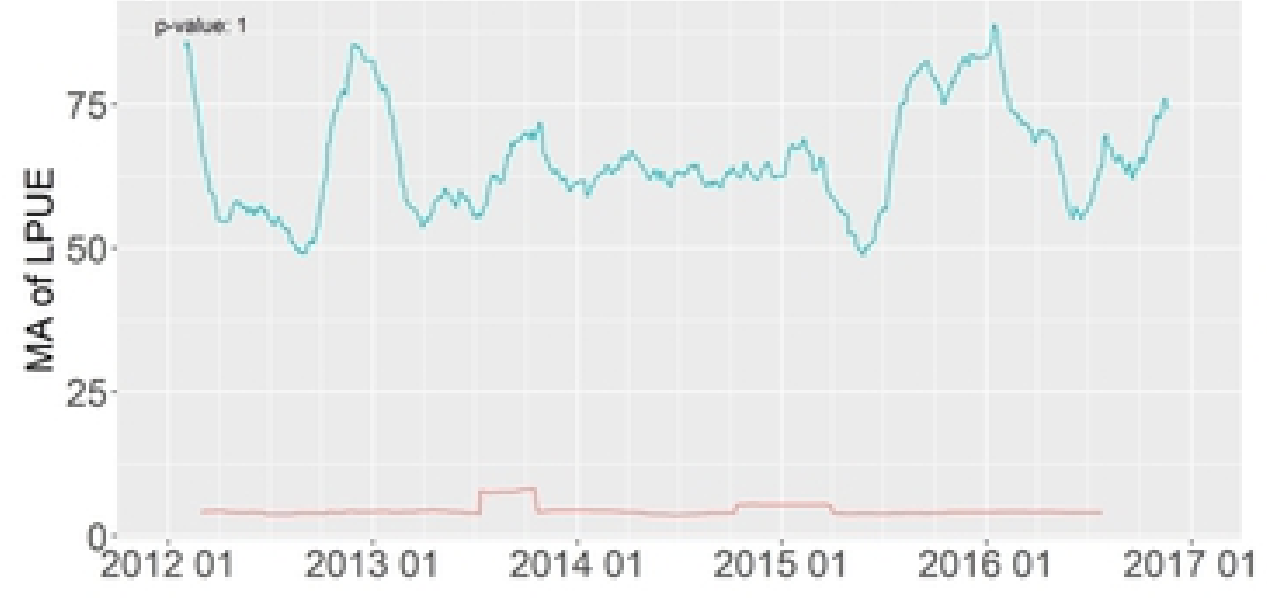

c) SOL - common sole

$$
\text { 年2. }
$$

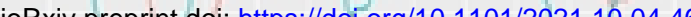

made available under aCC-BY 4.0 International license.
menten

$\begin{array}{llllll}201201 & 201301 & 201401 & 201501 & 201601 & 201701\end{array}$

e) WRF - wreckfish

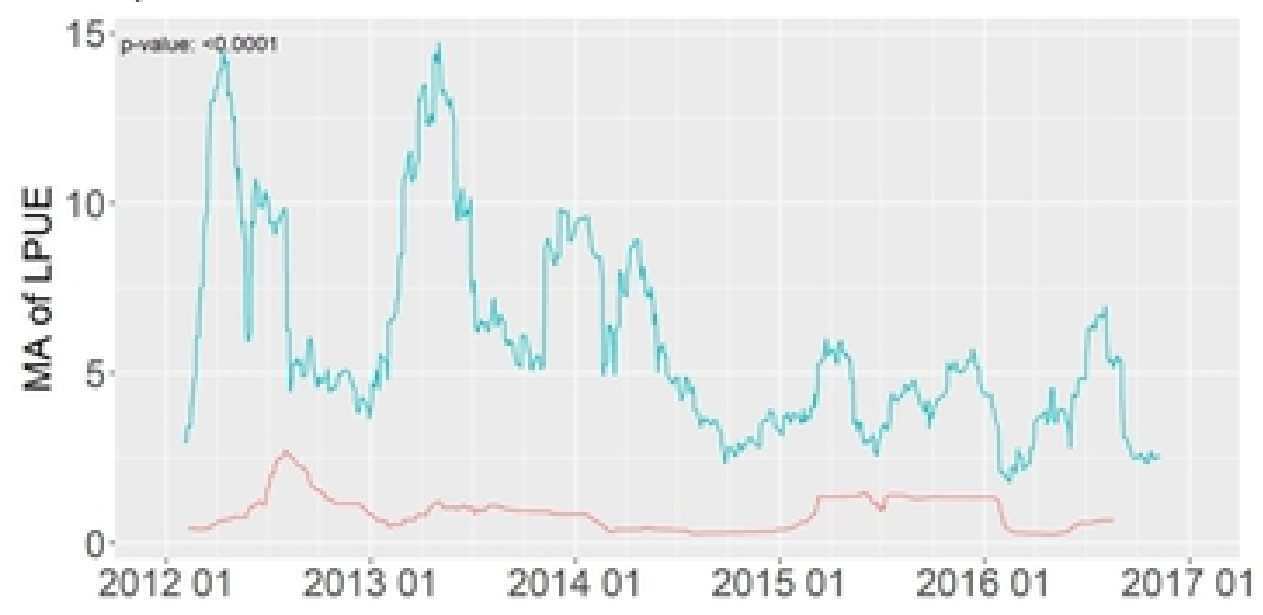

g) OCC - common octopus

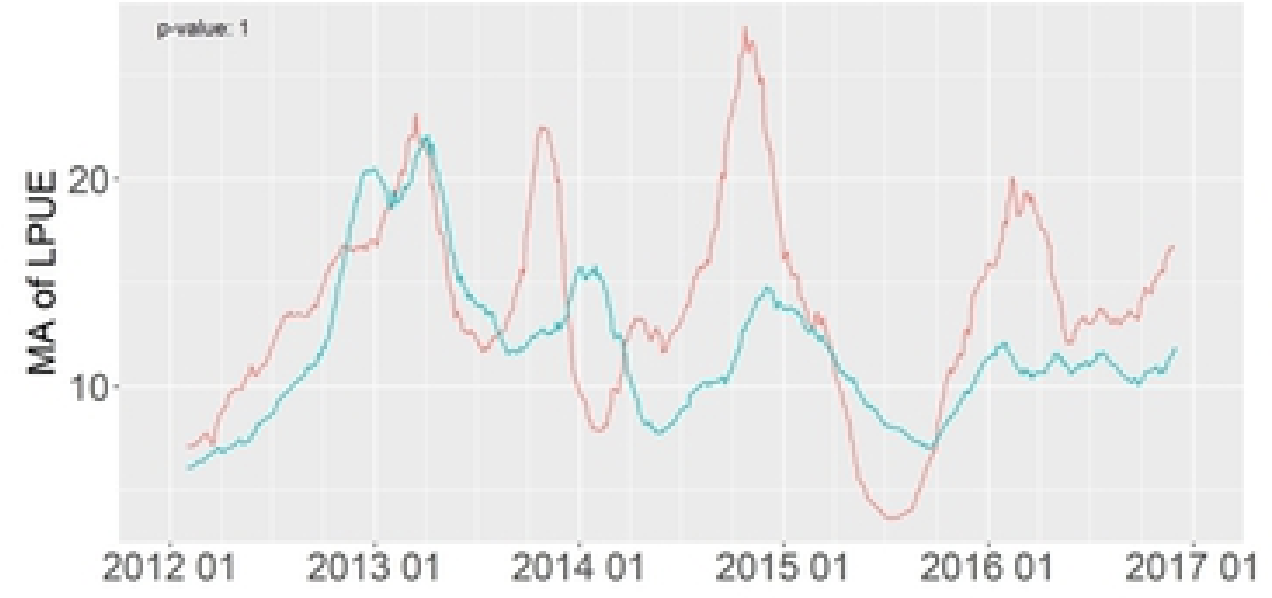

b) ANK - blackbellied angler

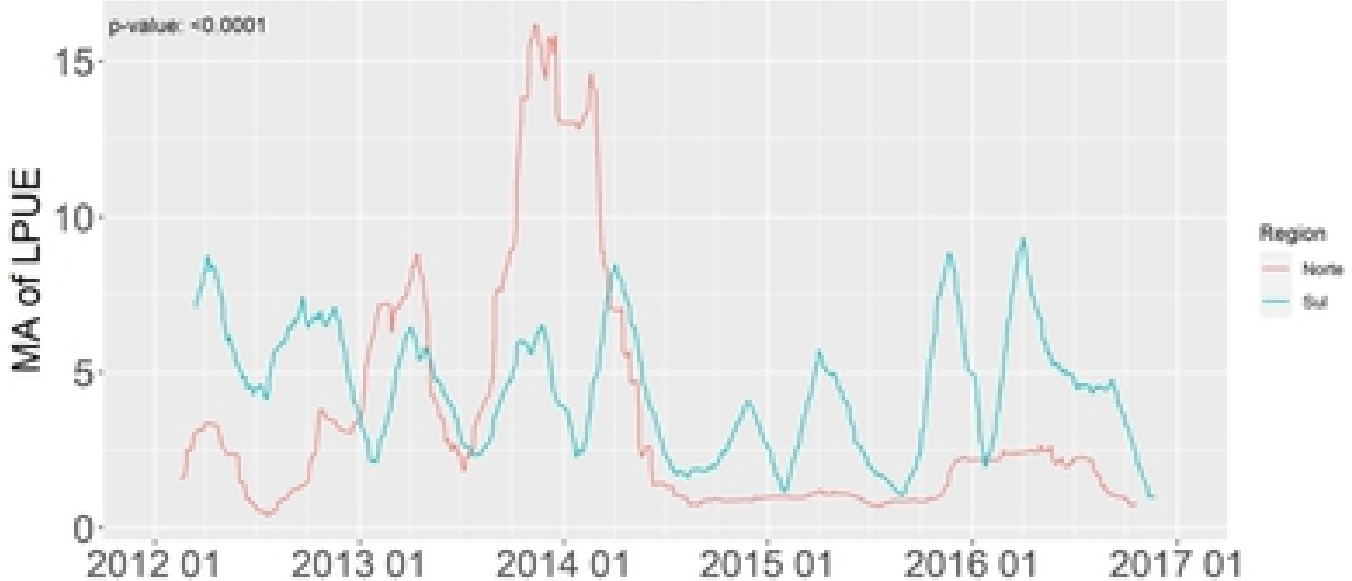

d) FOR - forkbeard

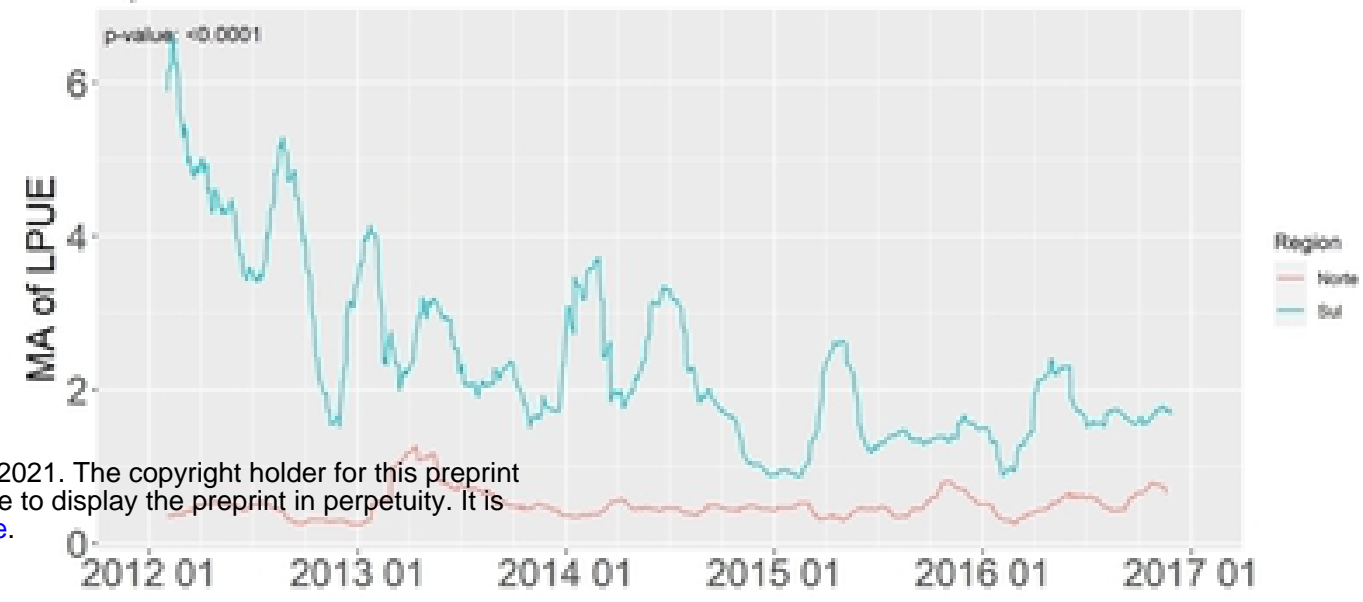

f) SMA - shortfin mako

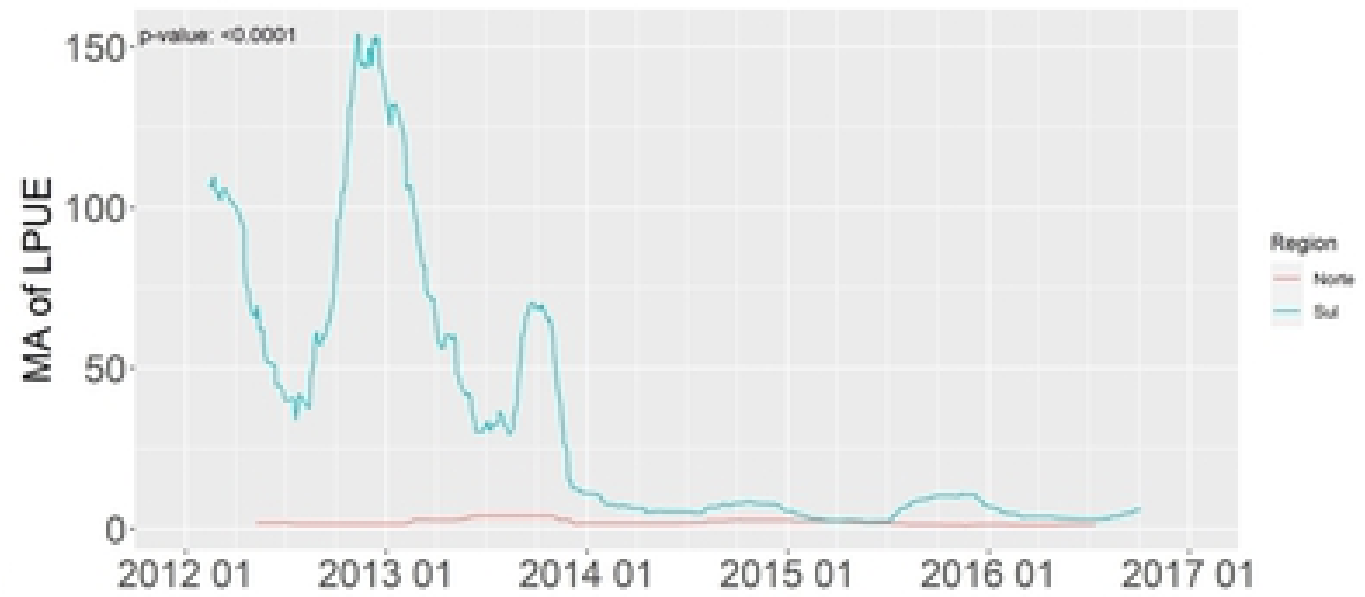

h) CTC - cuttlefish

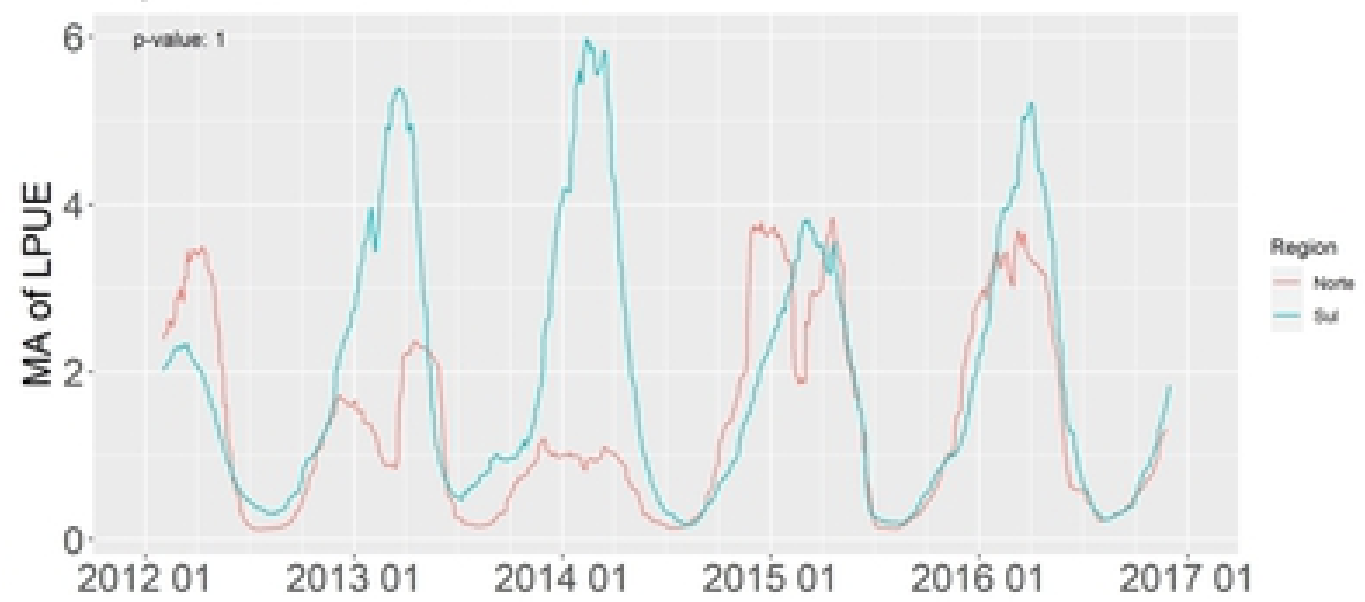



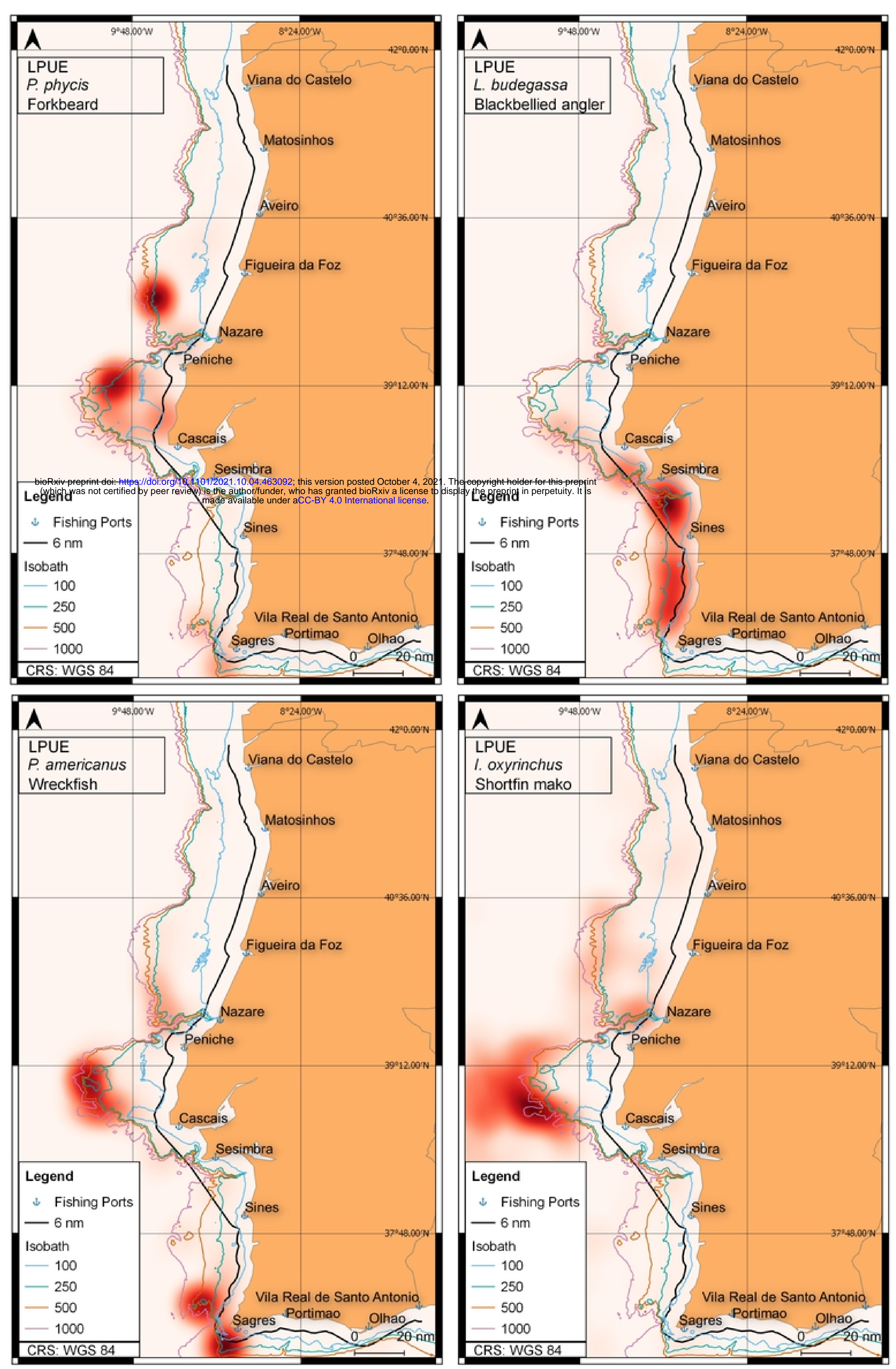

\section{Figure3}

